\title{
The optimal analgesic method in saline infusion sonogram: A comparison of two effective techniques with placebo
}

\author{
Salin infüzyon sonogramda en ideal analjezik yöntem: İki etkin \\ tekniğin plasebo ile karşılaştırılması
}

\author{
Sadullah Özkan1, Bülent Kars¹, Önder Sakin1 ${ }^{1}$, Aylin Onan Yılmaz¹, Yaren Tuba Bektaş¹, Halim Ömer Kaşıkç² \\ ${ }^{1}$ Dr. Lütfi Kırdar Training and Research Hospital, Clinic of Obstetrics and Gynecology, İstanbul, Turkey \\ ${ }^{2}$ Dr. Lütfi Kırdar Training and Research Hospital, Clinic of Family Medicine, İstanbul, Turkey
}

\begin{abstract}
Objective: Operations performed with local anesthesia can sometimes be extremely painful and uncomfortable for patients. Our aim was to investigate the optimal analgesic method in saline infusion sonograms.

Materials and Methods: This study was performed in our Clinic of Obstetrics and Gynecology between March and August 2011. Ninety-six patients were included. Patients were randomly divided into groups that received saline (controls, group 1), paracervical block (group 2), or paracervical block + intrauterine lidocaine (group 3). In all groups, a visual analogue scale score was performed during the tenaculum placement, while saline was administered, and 30 minutes after the procedure.

Results: When all the patients were evaluated, the difference in the visual analogue scale scores in premenopausal patients during tenaculum placement, during the saline infusion into the cavity, and 30 minutes following the saline infusion sonography were statistically different between the saline and paracervical block groups, and between the saline and paracervical block + intrauterine lidocaine group. However, there was no statistically significant difference between paracervical block and paracervical block + intrauterine lidocaine groups.

Conclusion: As a result of our study, paracervical block is a safe method to use in premenopausal patients to prevent pain during saline infusion sonography. The addition of intrauterine lidocaine to the paracervical block does not increase the analgesic effect; moreover, it increases the cost and time that the patient stays in the dorsolithotomy position by 3 minutes.
\end{abstract}

Keywords: Saline infusion sonography, pain, topical anesthesia, lidocaine

$\ddot{O} z$

Amaç: Sadece lokal anestezi ile uygulanan işlemler hastalar için bazen son derece ağrılı ve rahatsızlık verici olabilmektedir. Amacımız salin infüzyon sonogramlarda en ideal analjezik yöntemi araştırmaktır.

Gereç ve Yöntemler: Bu çalışmaya Mart-Ağustos 2011 tarihleri arasında hastanemiz Kadın Hastalıkları ve Doğum Kliniği'nden 96 hasta dahil edildi. Hastalar randomize olarak; serum fizyolojik kontrol grubu (1. grup), paraservikal blok (2. grup), paraservikal blok + intrauterin lidokain (3. grup) gruplarına ayrıldılar. Tüm gruplara, tenakulum sırasında, salin infüzyonu sırasında ve işlem uygulandıktan 30 dakika sonrasında vizüel analog skala skorları yapıldı. Bulgular: Tüm hastalar değerlendirildiğinde; premenopozal hastalarda tenakulum yerleștirildiğinde, kaviteye salin infüzyonu sırasında ve işlem yapıldıktan 30 dakika sonra uygulanan vizüel analog skala skorları arasında, serum fizyolojik grubu ile paraservikal blok grubu arasında ve serum fizyolojik grubu ile paraservikal blok + intrauterin lidokain grubu arasında anlamlı derecede fark tespit edilmiştir. Fakat paraservikal blok ile paraservikal blok + intrauterin lidokain grubu arasında anlamlı bir fark tespit edilmemiştir.

Sonuç: Araştırmamızın sonucunda, salin infüzyon sonogram sırasında paraservikal blok uygulaması premenopozal hastalarda ağrıyı etkin bir şekilde tek başına kesen, güvenle kullanabileceğimiz bir yöntem olarak gözükmektedir. Paraservikal blok sonrasında intrauterin lidokain eklenmesi işlem sırasındaki ağrıyı anlamlı şekilde kesmediği gibi, ekstra analjezik maliyetine ve hastanın 3 dakika daha fazla litotomi pozisyonunda kalmasına sebep olmaktadır.

Anahtar Kelimeler: Salin infüzyon sonogram, ağrı, topikal anestezi, lidokain

Address for Correspondence/Yazışma Adresi: Önder Sakin, MD,

Dr. Lütfi Kırdar Training and Research Hospital, Clinic of Obstetrics and Gynecology, İstanbul, Turkey

E-mail: sakin-onder@hotmail.com

Received/Geliș Tarihi: 25.01.2016 Accepted/Kabul Tarihi: 06.09.2016

(CTurkish Journal of Obstetrics and Gynecology, Published by Galenos Publishing House.

This article is distributed under the terms of the "Creative Commons Attribution NonCommercial 4.0 International Licence (CC BY-NC 4.0)". 


\section{Introduction}

There is a necessity to evaluate the endometrial cavity in many different gynecologic conditions. Pre and post-menopausal bleeding, endometrial lesions found with ultrasound, and evaluation of endometrial cavity before performing hysterectomy are some indications that may require saline infusion sonography $(\mathrm{SIS})(1,2)$.

The specificity and sensitivity of SIS for detecting endometrial pathology were $81-100 \%$ and $85-100 \%$, respectively. For detecting submucosal myoma, it has sensitivity of 57-100\% and specificity of 96-100\%. For detecting endometrial hyperplasia or cancer it has sensitivity of $29-80 \%$ and specificity of 82 $100 \%$ (3). In sum, SIS is a valuable and indispensable method in gynecology practice.

Unfortunately, SIS may cause pain and discomfort depending on the technique and methods of anesthesia. Grasping the cervix with a tenaculum, movement of cannulas in the uterus, and distention of the uterine cavity with saline may cause pain in the procedure. Hence, active cooperation of patients is highly desirable to obtain maximum efficacy, and effective anesthesia becomes very important. Paracervical block (PCB) is the most frequently used method to prevent pain in the procedure. Previous reports showed that intrauterine lidocaine (IUL) is also a safe and effective method for preventing pain in outpatient gynecologic procedures(4-9).

We designed a randomized controlled trial to compare the efficacy of PCB vs. IUL, and also with placebo.

\section{Materials and Methods}

We conducted this study between March 2011 and August 2011 in a tertiary reference center. The study was approved by our ethical committee. All participants gave their written informed consent for the study. We included 120 women who underwent SIS for various reasons. We excluded women with severe systemic medical conditions such as heart failure and uncontrolled severe hypertension, and cervical stenosis, acute cervicitis and/or vaginitis, and lidocaine allergy. The remaining 96 women were randomized into three groups: saline controls (group 1), PCB (group 2), and PCB + IUL (group 3); randomization was performed using computer-generated random number tables.

We collected data about patient characteristics including age, gravidity, parity, history of abortion, any known allergy, current drug use, and medical and gynecologic history from patient records.

All women underwent a bimanual pelvic examination to determine the size and position of the uterus. The cervix was exposed using a bivalve speculum and washed with povidoneiodine solution. In the PCB group, $2 \mathrm{~mL}$ 2\% lidocaine (Iekaine Ampoule, IE Ulagay, İstanbul, Turkey) was injected into the cervix at 4- and 8 o'clock positions at a depth of $2-3 \mathrm{~cm}$ after confirming the tip of needle was not inside a vessel lumen. Five minutes were allowed to pass to ensure the anesthetic effect of lidocaine had started. In the PCB + IUL group, an 18-gauge intravenous catheter was gently inserted into the cervical canal up to the internal os. Two milliliters of $2 \%$ lidocaine was injected into the uterine cavity. Again, 5 minutes were allowed to pass to ensure that the anesthetic effect of the lidocaine had begun. All forms of anesthetic methods were applied before grasping the cervix with a tenaculum. We used no anesthetic in the control group. Two milliliters of $0.9 \%$ saline solution was injected into the cervix at 4-and 8 o'clock positions instead of lidocaine. Five minutes were allowed to pass to create similar circumstances with the other groups. The cervix was grasped with a tenaculum at 11 - and 1 o'clock positions. A number 4 carmen cannula was inserted in the uterine cavity. The uterine cavity was filled with $50 \mathrm{~mL}$ of normal saline solution. The same operator performed all SIS procedures in the same way with help of the same nurse. Therefore, other variables that may affect pain score were controlled. A tenaculum was used in all patients in the standard procedure technique. Difficulty during passing the cervix and SIS findings were not recorded in our study.

We evaluated pain scores using a $10-\mathrm{cm}$ visual analogue scale (VAS), where $0 \mathrm{~cm}$ represented no pain and $10 \mathrm{~cm}$ represented worst pain imaginable. We evaluated pain scores at three different points: Immediately after installation of normal saline, at the end of the procedure, and 30 minutes after the procedure. All patients were prescribed $500 \mathrm{mg}$ azithromycin as prophylaxis.

Statistical calculations were performed using the Statistics Package for the Social Sciences (SPSS) for Windows version 13.0. Descriptive data are presented as mean \pm standard deviation or standard error. One-way ANOVA and Post-hoc Tukey tests were used to compare parametric variables and to compare differences between groups, respectively. A value of $\mathrm{p}<0.05$ was accepted as statistically significant.

\section{Results}

The ages of the 96 patients who participated in the study ranged from 23 to 62 years. The mean age of group 1 was $38.38 \pm 7.48$ years, group 2 was $35.25 \pm 8.08$ years, group 3 was $37.03 \pm 7.27$ years. There was no statistically significant difference between the mean ages of the groups ( $p>0.05$ ).

Of the patients included in the study, 16 were postmenopausal and 80 were premenopausal; group $1(n=32) 26$ premenopausal, 6 postmenopausal patients; group $2(n=32) 27$ premenopausal, 5 postmenopausal; and group $3(n=32) 27$ premenopausal, 5 postmenopausal patients.

The median scores of the groups were gravida $(2,3,3)$, living child $(2,2,2)$, abortion $(0,0,0)$, and curettage $(0,0,0)$ respectively. It has been found to disperse in accordance with the average of all these groups.

We found significant differences between groups at tenaculum placement. We used the Post-hoc Tukey test to determine which group had the statistically significant score. We found that pain 
scores were significantly higher in the control group $(\mathrm{p}=0.002)$, but there was no significant difference between either study group ( $\mathrm{p}=0.596)$.

After the injection of sterile saline solution, the control group had significantly increased pain scores, different from both study groups $(\mathrm{p}=0.045)$. We found no significant difference between either study group at this point $(\mathrm{p}=0.835)$. During tenaculum use, the mean pain in the group 1 was $27.40 \pm 25.58$, group 2 was $21.74 \pm 23.25$, and group 3 was $11.74 \pm 11.54$ (Graphic 1). During saline infusion, the mean pain in the group 1 was $25.20 \pm 27.66$, group 2 was $29.12 \pm 14.56$, and group 3 was 20.63 \pm 19.50 (Graphic 2) (Table 1, 2, 3).

\section{Discussion}

Patients experience pain in gynecologic outpatient diagnostic interventions. We aimed to determine whether it was correct to use different anesthetic methods in daily clinical practice, and thus we compared PCB and PCB + IUL with placebo.

In the study of Guney et al.(5), IUL that was applied just after buccal misoprostol was found effective preventing pain. IUL failed to prevent pain in procedures such as endometrial biopsy or hysterosalpingograhy in other studies(6,7). Guney et al.(5) attributed this difference to the combined use of lidocaine with other drugs. Though there was no significant difference between study groups, we also find that lidocaine decreased pain with statistical significance. The reason of this result may be the limited local effect of lidocaine. Patients feel pain the most at the time of grasping the cervix with a tenaculum and the insertion of a carmen cannula. Lidocaine shows its anesthetic effect through free nerve endings as described in previous studies. Guney et al.(5) found that pain was decreased in their IUL group during endometrial curettage. We did not perform endometrial biopsy, instead only the uterine cavity was distended in our study. We found no significant differences, probably because we performed a less painful procedure than that of Guney et al.(5).

$\mathrm{PCB}$ and $\mathrm{PCB}+\mathrm{IUL}$ were effective at preventing pain in all premenopausal women in our study. The same effect could not be shown in postmenopausal women. To our knowledge, no studies have compared pain scores of women according to their menopausal status. Only Guney et al.(5) noted that combined use of IUL and misoprostol was effective at preventing pain in premenopausal women, whereas it was not effective in postmenopausal women. More randomized

Table 1. Demographic characteristics of the groups

\begin{tabular}{|c|c|c|c|c|}
\hline & $\begin{array}{l}\text { Group } 1 \\
\text { Saline } \\
(n=32)\end{array}$ & $\begin{array}{l}\text { Group } 2 \\
\text { PCB } \\
(n=32)\end{array}$ & $\begin{array}{l}\text { Group } 3 \\
\text { PCB + IUL } \\
(n=32)\end{array}$ & $\mathrm{p}$ \\
\hline Gravid* & 2 & 3 & 3 & NS \\
\hline Living child* & 2 & 2 & 2 & NS \\
\hline Abortus* & 0 & 0 & 0 & NS \\
\hline Curettage* & 0 & 0 & 0 & NS \\
\hline Premenopausal (n) & 26 & 27 & 27 & NS \\
\hline Postmenopausal (n) & 6 & 5 & 5 & NS \\
\hline Age $^{* *}$ & $38.38 \pm 7.48$ & $35.25 \pm 8.08$ & $37.03 \pm 7.27$ & NS \\
\hline
\end{tabular}

Table 2. The visual analogue scale scores of all patients during tenaculum use during saline infusion sonogram

$\begin{array}{llll} & \text { Saline } & \text { PCB } & \text { PCB + IUL } \\ \text { Saline } & - & \mathrm{p}=0.002[95 \% \mathrm{CI}:(4.33-21.91)] & \mathrm{p}<0.001 \text { [95\% CI: (7.92-25.51)] } \\ \text { PCB } & - & - & \mathrm{p}=0.596 \text { [95\% CI: }(-5.20-12.38)]\end{array}$

PCB: Paracervical block, IUL: Intrauterine lidocaine, CI: Confidence interval

Table 3. Visual analogue scale scores of all patients during saline infusion into the uterine cavity

$\begin{array}{lllll} & \text { Saline } & \text { PCB } & \text { PCB + IUL } \\ \text { Saline } & - & \mathrm{p}=0.045 \text { [95\% CI: (0.28-29.15)] } & \mathrm{p}=0.010 \text { [95\% CI: (3.75-32.6)] } \\ \text { PCB } & - & - & \mathrm{p}=0.835 \text { [95\% CI: }(-10.9-17.9)]\end{array}$

PCB: Paracervical block, IUL: Intrauterine lidocaine, CI: Confidence interval 


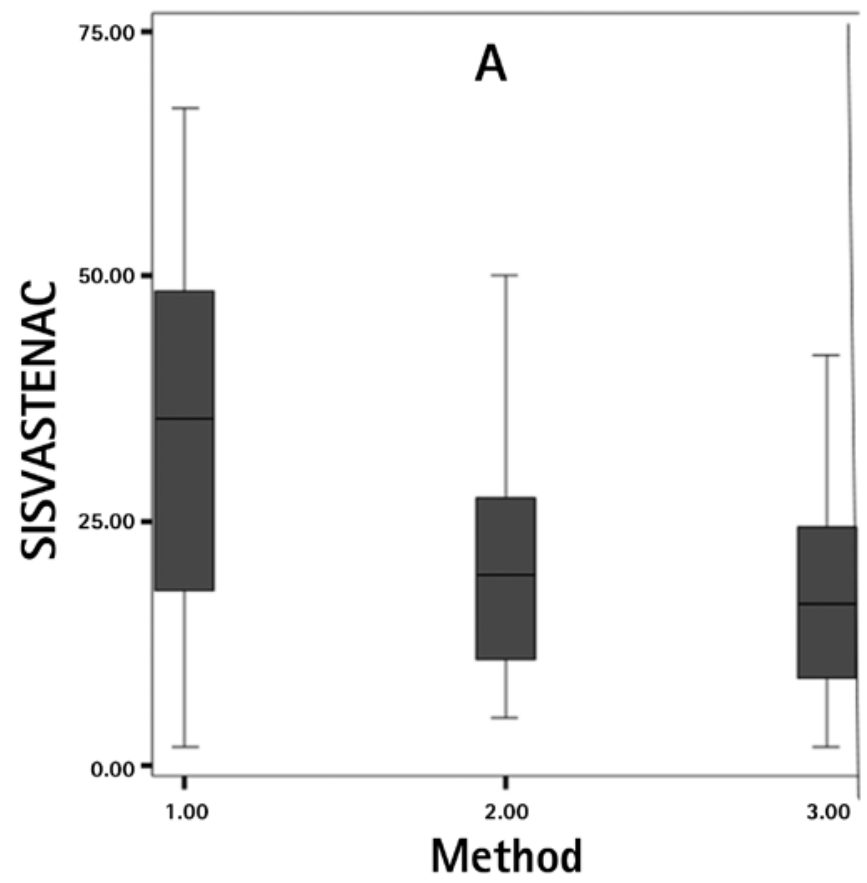

Graphic 1. Graph showing the mean \pm standard deviation D values of pain visual analogue scale scores during tenaculum application SIS: Saline infusion sonography, VAS: Visual analogue scale, TENAC: Tenaculum

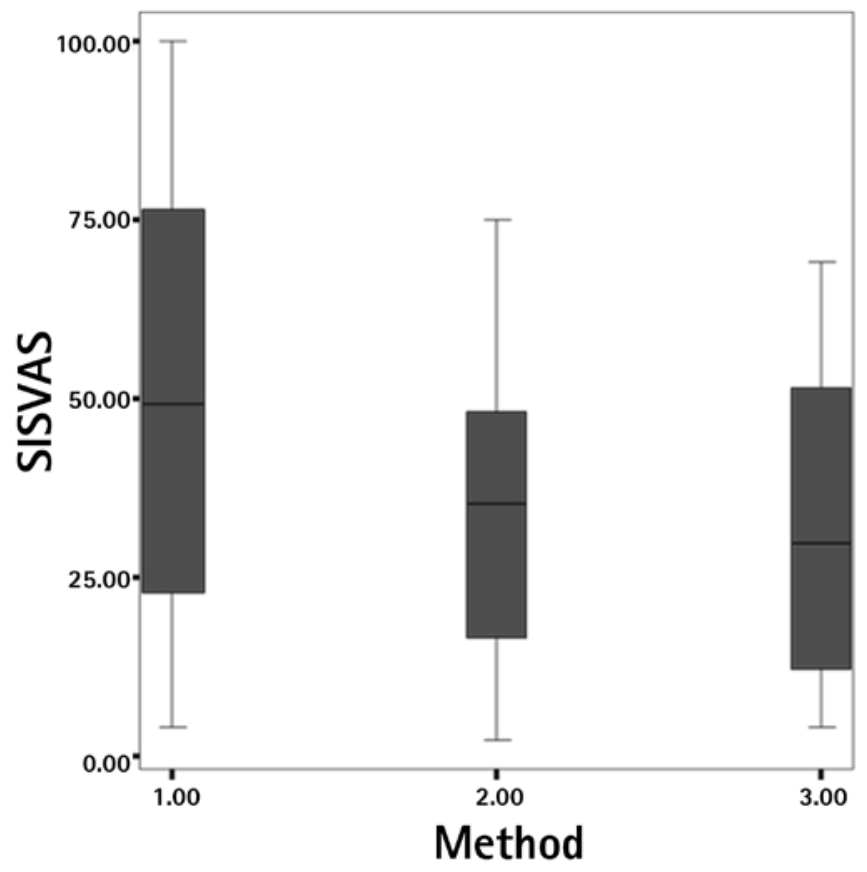

Graphic 2. The graph showing the mean \pm standard deviation values of pain visual analogue scale scores during saline infusion into the uterine cavity

SIS: Saline infusion sonography, VAS: Visual analogue scale studies are warranted to determine which anesthetic method would be appropriate for postmenopausal women in outpatient gynecologic procedures.

Van den Bosch et al.(8) compared gel infusion sonography with SIS in their study of 2009. They found both methods were similar in use but pain caused by the procedure was heightened in SIS. They attributed this difference to the lubricant effect of gel, which made it easier to pass the instrument through the cervix. In their second study, they compared gel infusion sonography alone with gel infusion sonography plus IUL. The authors could not show significant differences in the mean VAS scores. Performing SIS is much easier than gel infusion sonography in outpatient settings. Moreover, the long-term effect of gel use remains unknown ${ }^{(9)}$.

The effect of different anesthetic methods on endometrial curettage, hysterosalpingograhy, and hysteroscopy has been extensively studied. The results are conflicting because of the different natures of the procedures. We think our study will help those who need an effective method to prevent pain in SIS.

\section{Conclusion}

In conclusion, paracervical block is effective at preventing pain in premenopausal women undergoing SIS. The addition of IUL to PCB does not decrease pain but increases both the time and cost of the procedure.

\section{Ethics}

Ethics Committee Approval: The study were approved by the Dr. Lütfi Kirdar Training and Research Hospital Local Ethics Committee, Informed Consent: Consent form was filled out by all participants. Peer-review: External and Internal peer-reviewed.

\section{Authorship Contributions}

Surgical and Medical Practices: Sadullah Özkan, Aylin Onan Yilmaz, Yaren Tuba Bektaş, Concept: Sadullah Özkan, Bülent Kars, Design: Sadullah Özkan, Bülent Kars, Data Collection or Processing: Sadullah Özkan, Aylin Onan Yılmaz, Yaren Tuba Bektaş, Analysis or Interpretation: Sadullah Özkan, Önder Sakin, Halim Ömer Kaşıkçı, Literature Search: Sadullah Özkan, Önder Sakin, Writing: Sadullah Özkan, Önder Sakin, Halim Ömer Kaşıkçı.

Conflict of Interest: No conflict of interest was declared by the authors.

Financial Disclosure: The authors declared that this study has received no financial support.

\section{References}

1. Bingol B, Gunenc Z, Gedikbasi A, Guner H, Tasdemir S, Tiras B. Comparison of diagnostic accuracy of saline infusion sonohysterography, transvaginal sonography and hysteroscopy. J Obstet Gynaecol 2011;31:54-8.

2. Chawla I, Tripathi S, Vohra P, Singh P. To Evaluate the Accuracy of Saline Infusion Sonohysterography (SIS) for Evaluation of Uterine Cavity Abnormalities in Patients with Abnormal Uterine Bleeding. J Obstet Gynaecol India 2014;64:197-201. 
3. Farquhar C, Ekeroma A, Furness S, Arroll B. A systematic review of transvaginal ultrasonography, sonohysterography and hysteroscopy for the investigation of abnormal uterine bleeding in premenopausal women. Acta Obstet Gynecol Scand 2003;82:493-504.

4. Jareethum R, Suksompong S, Petyim S, Prechapanich J, Laokirkkiat P, Choavaratana R. Efficacy of mefenamic acid and hyoscine for pain relief during saline infusion sonohysterography in infertile women: a double blind randomized controlled trial. Eur J Obstet Gynecol Reprod Biol 2011;155:193-8.

5. Guney M, Oral B, Mungan T. Intrauterine lidocaine plus buccal misoprostol in the endometrial biopsy. Int J Gynaecol Obstet 2007;97:125-8.

6. Dogan E, Celiloglu M, Sarihan E, Demir A. Anesthetic effect of intrauterine lidocaine plus naproxen sodium in endometrial biopsy. Obstet Gynecol 2004;103:347-51.
7. Costello MF, Horrowitz S, Steigrad S, Saif N, Bennett M, Ekangaki A. Transcervical intrauterine topical local anesthetic at hysterosalpingography: a prospective, randomized, double-blind, placebo-controlled trial. Fertil Steril 2002;78:1116-22.

8. Van den Bosch T, Betsas G, Van Schoubroeck D, Daemen A, Vandenbroucke V, Cornelis A, et al. Gel infusion sonography in the evaluation of the uterine cavity. Ultrasound Obstet Gynecol 2009;34:711-4.

9. Van den Bosch T, Verguts J, Daemen A, Gevaert O, Domali E, Claerhout F, et al. Pain experienced during transvaginal ultrasound, saline contrast sonohysterography, hysteroscopy and office sampling: a comparative study. Ultrasound Obstet Gynecol 2008;31:346-51. 